4. Швечкова Ю. О., Бездітко А. Р. Мотивація курсантів нефілологічного напрямку підготовки до вивчення іноземних мов. Методика та специфіка викладання іноземних мов у закладах вищої освіти: тези доповідей всеукраїнської науково-методичної конференції (Харків, 7 грудня 2020 р.). Харків: Національна академія Національної гвардї України, 2020. С. 92-94.

5. Deci E., Ryan R. Intrinsic and Extrinsic Motivations: Classic Definitions and New Directions. Contemporary Educational Psychology. 2000. № 25. P. 54-67.

DOI https://doi.org/10.30525/978-9934-26-039-1-103

\title{
ТРИЛІНГВІЗМ У ПРОЦЕСІ НАВЧАННЯ ГРАМАТИКИ АНГЛІЙСЬКОЇ МОВИ
}

\author{
Шепітчак В. А. \\ кандидат педагогічних наук, \\ викладач кафедри англійської філологї \\ та методики навчання англійської мови \\ Тернопільського національного педагогічного університету \\ імені Володимира Гнатюка \\ м. Тернопіль, Украӥна
}

Методика навчання IM2 тісно пов'язана 3 таким лінгвістичним явищем, як трилінгвізм. М. Баришніков і М. Бодоньї визначають його як співіснування трьох мов у мовленнєво-мисленнєвій сфері індивіда, що використовує їх у різних комунікативних цілях відповідно до мети спілкування [1, с. 30]. А. Щепілова стверджує, що трилінгвізм дає можливість для постійного порівняння, зіставлення (свідомого i несвідомого) засобів висловлювання думки різними мовами. Володіння студентами механізмами РМ та німецької мови як першої іноземної мови пов'язано 3 такими процесами, як мислення, пам'ять, лінгвістичний досвід, що є основою для мисленнєво-мовленнєвої діяльності людини [13, с. 17]. Аналіз досліджень з питання багатомовності (А. Карлінський, Б. Маруневич, Н. Мечковська, В. Розенцвейг, Т. Руднєва, Е. Хауген, Л. Щерба й ін.) дає змогу визначити два основні підходи до вивчення IM2: лінгвістичний і психолінгвістичний [7].

Основною причиною виникнення помилок дослідники вважать несумісність у лінгвістичних системах трьох мов, коли системи трьох 176 
мов накладаються одна на одну, що призводить до помилкових протиріч при їх контакті [9, с. 13]. Внаслідок цього виникає помилкова аналогія, яка призводить до підміни схем і моделей ІМ відповідними елементами РМ або зміни перших за прикладом других [3, с. 46]. Відповідно, основним способом полегшення засвоєння іноземної мови та вдосконалення процесу навчання вважається прогнозування на основі порівняльного аналізу труднощів, що виникають при вивченні мови студентами факультету іноземних мов, і розробки шляхів подолання виявлених труднощів $[3 ; 4 ; 11 ; 12]$.

Виявлення об'єктивних труднощів засвоєння граматичних явищ дало підстави зробити висновок про те, що вони полягають у збігах $\mathrm{i}$ розбіжностях граматичних явищ у рідній, першій та другій іноземних мовах які супроводжуються трансференцією ци інтерферениією. Тому запобіганню інтерференції сприяє вивчення відповідних граматичних явищ у порівнянні їх 3 мовами, які вже вивчалися раніше. Це зумовило визначення лінгвістичного компоненту змісту навчання граматичної сторони мовлення, що повинен містити, в першу чергу, ті граматичні поняття, що відсутні в українській та німецькій мовах або мають свої особливості: артикль, герундій, порядок слів у реченні та ін. Нехтування ними може власне і зумовити інтерференцію. Навчання граматичного аспекту мови на заняттях 3 другої іноземної мови у виші має бути орієнтоване: а) на врахування лінгвістичного досвіду тих, хто навчається, він здобувається у процесі оволодіння трьома контактними мовами (українською, англійською, німецькою) і б) на цілеспрямоване використання набутого досвіду при оволодінні структурами другою іноземною мовою.

На думку Л. Орловської, формування граматичної компетентності у майбутніх філологів має бути тісно пов'язане 3 формуванням мовленнєвої, соціокультурної, стратегічної компетентності, що складають основу всіх описаних компетентностей, а також професійної компетентності, що формується у процесі підготовки майбутнього філолога. Такий висновок може свідчити про наявність поряд з базовим мовним компонентом відповідних компонентів у складі граматичної компетентності [7, с. 51]. На думку, Н. Бориско, граматична компетентність $є$ цільовою компетенцією на початковому етапі навчання у вишах і входить до складу інших компетенцій на наступних етапах навчання, опосередковуючи їх та удосконалюючись за їх рахунок [3, с. 235].

Мовний компонент граматичної компетентності складається 3 граматичних знань, які $€$ основою для функціонування рецептивних $\mathrm{i}$ репродуктивних навичок. На думку вчених $[5 ; 6 ; 8 ; 11 ; 12]$, граматичні 
знання першої іноземної мови - це цілеспрямовано відібрана, підготовлена і упорядкована граматика, яку студент повинен засвоїти протягом курсу вивчення інозенмої мов [7; 10; 14]. У свою чергу вивчення мови грунтується на двох взаєпов'язаних видах знань - імпліцитних та експліцитних. Імпліцитні знання - це інтуїтивна інформація, якою студенти оперують у процесі мовленнєвої діяльності, а експліцітні знання - це усвідомлення знань про мову [10, с. 52]. N. Ellis вважає, що отримання знань відбувається за допомогою експліцитного навчання та імпліцитного оволодіння. Експліцитне навчання - це свідомий процес отримання знань. Експліцитне навчання поділяється на заучування та вирішення проблем. Імпліцитне оволодіння - це процес набуття знань про мовні форми, який протікає несвідомо і природно. Імпліцитне оволодіння - це оволодіння через зразки, та вивчення через правила $[15$, с. $232 ;]$. Експліцитне навчання та імпліцитне оволодіння можуть бути організовані дедуктивно від правил до прикладів та індуктивно від прикладів до правил [11, с. 314; 210]. Експліцитні та імпліцитні знання можуть взаємодіяти.

Ми погоджуємося 3 Т. Стеченко, що формування граматичної компетентності неможливе без урахування соціокультурного фактора, оскільки знання значеннь слів і правил граматики недостатні для володіння мовою як засобом спілкування. Лише врахування соціокультурних реалей мови, що вивчається, і РМ, при співставленні іноземної мови з рідною і чужої культури з рідною, усі тонкощі та вся глибина проблем міжмовної та міжкультурної комунікації стають особливо явними [10, с. 126]. Основою соціокультурного компоненту є знання про національно-культурну специфіку мовленнєвої поведінки і здатності користуватися тими елементами соціокультурного контексту, які $\epsilon$ важливими для породження та сприйняття мовлення з точки зору носіїв мови: звичаї, правила, норми, соціальних умовностей [1, с. 333]. Процес навчання граматики повинен бути спрямованим на формування іншомовної граматичної компетентності з урахуванням національнокультурних особливостей мови, що вивчається, в складі професійної іншомовної комунікативної компетентності, необхідної для здійснення майбутньої професійної діяльності. Зміст граматичної компетентності, окрім знань елементів мови та вміння їх використовувати в мовленні, повинен включати також знання, навички та вміння, які сприяють засвоєнню соціально-культурних норм i національно-культурних особливостей мовленнєвої поведінки представників англомовної культури. 
Відповідно під граматичною компетентністю ми розуміємо: здатність розуміти й виражати значення, продукувати і розпізнавати правильно оформлені фрази і речення (що $є$ протилежним заучуванню та відтворенню ї як стійких формул); неусвідомлене вживання граматичних форм рідної та іноземної мов згідно із законами і нормами граматики (рід, число, відмінок тощо), чуття граматичної форми, наявність корекційних навичок щодо правильності вживання граматичних форм; внутрішне невербалізоване знання граматичної системи мови, знання морфологічної та синтаксичної системи мови (типології форм), а також набору правил.

\section{Література:}

1. Азимов Э. Г. Словарь методических терминов (теория и практика преподавания языков). СПб. Златоуст, 1999. 472 с.

2. Барышников Н. В. Английский язык как доминантный в обучении многоязычию. Иностранные языки в школе. 2007. № 5. С. 29-33.

3. Борецька Г. Е. Методика навчання студентів-філологів граматично правильної англомовної писемної комунікації: дис. ... кандидата пед. наук: 13.00.02. К., 2004. 245 с.

4. Вайнрайх У. Одноязычие и многоязычие. Новое в лингвистике. М., 1972. Вып. 6 : Языковые контакты. С. 25-60.

5. Гальскова Н. Д. Теория обучения иностранным языкам: лингводидактика и методика : учеб. пособие для студ. лингвистических и филологических факультетов высш. учеб. заведений.М.: Академия, 2004. $336 \mathrm{c}$.

6. Мельник И. М. Обучение студентов-филологов письму на английском языке как втором иностранном (первый год обучения): дис. ... канд. пед. наук : 13.00.02. К., 2001. 256 с.

7. Миськів В. А. Граматична інтерференція як методична проблема у процесі вивчення англійської мови як другої іноземної. Матеріали другої всеукраїнської науково-практичної конференції: Новітні тенденції навчання іноземної мови за професійним спрямуванням. Херсон, 2013. Вид-во Херсонської державної морської академії, 2013. С. 221-224.

8. Миськів В.А. Прояв граматичної інтерференції у процесі вивчення англійської мови як другої іноземної. Науковий вісник Ужгородського національного університету. Сер.: Педагогіка. Соціальна робота. Ужгород, 2014. Вип. 31. С.101-103.

9. Орловська Л. К. Формування граматичної компетенції в усному мовленні на засадах інтегрованого навчання у майбутніх вчителів англійської мови : дис. ... канд. пед. наук : 13.00.02. К., 2010. 304 с. 
10. Филиппова Т. И. Принцип систематизации при обучении грамматике. М. : [б. и.], 2002. 240 с.

11. Щепилова А. В. Коммуникативно-когнитивный подход к обучению французскому как второму иностранному. М.: Школьная книга, 2003. 488 c.

12. Щепилова А. В. О проблеме обучения второму иностранному языку в общеобразовательной школе. Содержание обучения иностранным языкам в школе и вузе. М., 2003. С. 16-21.

13. Bialistok E. Representation and Ways of Knowing : Three Issues in Second Language Acquisition. London, 1994. P. 549-569.

14. Lekova B. Language Interference and Methods of its Overcoming in Foreign Language Teaching. Trakia Journal of Science. 2010. Vol .8, Suppl 3. P. 320-324.

15. Swan M.. A Teacher Guide to Interference and Other Problems. Cambridge : Cambridge University Press, 2002. 365 p.

16. Yeonhwan Lyn Simulations and Second Foreign Language Learning: Improving communication skills through simulations. Thesis. The University of Toledo, 2006. 46 p. 